\title{
Universities' Engagement with Vocationalism: Historical Perspective
}

\author{
Pericles 'asher' Rospigliosi;, Tom Bourner, and Linda Heath \\ University of Brighton, Brighton Business School, Mithras House, Lewes Road, Brighton BN2 \\ 4AT, United Kingdom
}

Received: 29.08.2016; Accepted: 04.10.2016; Published: 19.12.2016

\begin{abstract}
The aim of this article is to explore the historical context of vocationalism in universities. It is based on an analysis of the history of the university from a vocational perspective. It looks for evidence of vocational engagement in the activities of universities over time, taking a long view from the birth of the Western University in the Middle Ages to the 1980s with the emergence of current issues of vocationalism in university education. It adopts a chronological perspective initially and then a thematic one. The main findings are: (1) vocationalism in university education is as old as the Western University itself, (2) there is evidence from the start of the Western University of vocational engagement in terms of the provision of vocationally relevant subjects, vocationally relevant skills and the development of vocationally relevant attitudes, (3) whereas most graduate employers used to be concerned with the vocationally relevant knowledge, skills and attitudes students acquired on their degree courses, most are now more concerned with graduate capacity and disposition to learn within their employment after graduation and (4) subject-centred education is compatible with university education that supports the vocational aspirations of students.
\end{abstract}

Keywords: VET, Vocational Education and Training, Graduate employability, Graduate unemployment, Learned professions, Vocational relevance, New vocationalism, Graduate destinations, Graduate jobs

\footnotetext{
*Corresponding author: a.rospigliosi@brighton.ac.uk
}

ISSN: 2197-8646

http://www.ijrvet.net 


\section{Introduction}

An enduring belief holds that historically, the Western University has been dedicated to the advancement of knowledge for its own sake. According to this view, university education used to be about involving students in the common pursuit of knowledge and developing their capacity to test assertions, evidence and conclusions. From this perspective, there has been a relatively recent drift towards vocationalism, including the development of skills for graduate employment and preparation for work-readiness. This is a story about the invasion of university education located in the higher domains of the mind, the pursuit of excellence and intellectual endeavour by a lower form of university education focused on employment, income and material well-being. This account of the demise of the real university education of bygone days has been advanced as a kind of philistinism in many books in recent decades asserting the decline of the university and university education, including, for example, Maskell and Robinson (2002), Graham (2002), Bailey and Freedman (2011) and Collini (2012). Nothing could be further from the truth. Universities engagement with vocationalism and graduate employment is not new; it is as old as the Western University itself and has been an issue in each stage of the development of the university since then. It is not possible to understand fully the Western university or its history without understanding its interest in the employment of its graduates. When we use the term vocationalism in university education we mean a university education that prepares students for employment, as well as, of course, others aspects of their lives, after graduation. That is the main conclusion of this paper. Other conclusions are:

1. Universities engagement with vocationalism can be partitioned into three parts: (i) the inclusion of vocational subject content, (ii) the development of vocationally relevant skills, and (iii) the development of attitudes that support vocational aspirations. These three parts of university vocational engagement can be found in all the stages of the development of the Western university.

2. In the past, graduate employability has depended largely on the acquisition of knowledge, skills and attitudes that graduates could apply in employment. As the pace of change has accelerated the employability of graduates depends increasingly on the ability of new graduates to persuade prospective employers of their capacity, and disposition, to learn in their employment after graduation.

3. Subject-centred university education is compatible with university education that supports the vocational concerns of universities and their students.

Why is this an important issue? Graduate employability is important to current students and recent graduates (and their families) as it affects their current well-being and future prospects. It is important to universities because it is a performance indicator affecting their status, funding and ability to recruit the students they want. And it is important to the government and society at large because the higher education of students is costly 
and graduates who remain unemployed or underemployed can be viewed as a waste of resources.

But why is its history and development important? There are three main reasons. First, understanding anything can be enhanced by understanding its contexts, including its historical context. Placing graduate employability into its historical context helps us to understand the bigger picture and a paper on the history and development of universities' engagement with vocationalism can help people focused on a specific issue appreciate where they are located within that bigger picture. This means that this article should be helpful to people researching specific issues within the domain of vocationalism in university education. Second, attitudes to vocationalism in university education depend, at least in part, on expectations which depend, in turn, on perceptions of graduate employability in the past. Greater knowledge of the history of vocationalism in university education can therefore help explain current attitudes, values and beliefs about it. Third, exploring the history of vocationalism in university education may produce lessons that are relevant to modern attempts to enhance graduate employability.

This paper starts by summarising what we know about vocationalism in each of the main stages of the Western University. It adopts a chronological approach and offers a brief history of vocationalism in university education. The second part of the paper offers a thematic approach i.e. it distils key themes in university attempts to enhance the employability of their graduates. This part develops a framework of vocational engagement from the earliest (medieval) stage and then uses it to explore vocationalism in each of the subsequent periods. After that, various emergent issues are discussed, including the particular stages we have used to partition the history of the Western university, proliferation of subject disciplines within university education, 'moral panic' surrounding vocationalism in university education, and historicism as a guide to future vocationalism in university education. The overall theoretical framework of this article is critical realism (Bhaskar, 2010; Sayer, 2010). Interpretations of the history of universities are constrained by what constitutes the 'best' current evidence-based knowledge in this field. The specific framework of the article is so-called 'new vocationalism', a theory of graduate employment which resolves the conundrum that the majority of graduate job vacancy advertisements are open to graduates of any subject discipline and fits the empirical data on graduate employment (Bourner and Rospigliosi, 2008; Bourner et al., 2011).

The current debates on student employability and vocationalism in university education really took off after the steep rise in graduate unemployment in the early 1980s. Since that time, the issues are too well-known and recent to need repeating. Our purpose in writing this paper is to offer the historical context within which these debates are framed. For this reason, our account of the historical context does not continue into the 1980s when the current debates began. 


\section{Background}

\subsection{Graduate employment in the medieval university}

The Medieval University was intimately associated with the Latin Church (Pederson, 1997). The Latin Church contained the most learned people in Western Christendom when the European University was born. Most of the earliest universities of Europe emerged from cathedral schools of the Latin Church following the papal decree issued in 1079 (by Pope Gregory VII) instructing all cathedrals to establish schools to train those who would be needed to serve a Latin Church which was growing in terms of geography, power and ambitions (Southern, 1970). It was from these cathedral schools tasked with providing an education for future clerics that most of the earliest universities of Europe emerged. The primary purpose of the cathedral schools was to provide an educated clergy to staff the enlarged operations of the Latin Church (Rudy, 1984). The $11^{\text {th }}$ century was a period of expansion of the Latin Church in terms of geography, power and wealth. New bishoprics were established across Europe (Bartlett, 1993).

By 1077 the growing power of the Church over secular rulers was symbolised by the abasement of the ruler of Latin Europe's largest territory, the Holy Roman Emperor, before the Pope at Canossa. In England, by the time of the Doomsday Book in 1086, the Latin Church already controlled a fifth of the kingdom's resources and it would soon control much more. Expansion of the Roman Church in the $11^{\text {th }}$ century meant that the Church needed a much greater supply of clergy to support its enlarged size and power. Latin Christianity is a text-based religion; its authority rests on Holy Scripture, particularly the 'Holy Bible'. The very word 'scripture' of course refers to written text. Even Islam referred to Christians (and Jews) as 'people of the Book' (Burnett, 1997). Consequently, the expanding Latin Church needed an enlarged supply of educated clergy. The curriculum of the early universities, based on the trivium, quadrivium and study of Holy Scripture, reflected that purpose. The $12^{\text {th }}$ century saw the continued rise of the Latin Church and the emergence of Europe as a theocracy. From the seeds sown in the $11^{\text {th }}$ century grew institutions in the $12^{\text {th }}$ and $13^{\text {th }}$ centuries that are recognised as universities (Haskins, 2002). The universities that were established in the $12^{\text {th }}$ and $13^{\text {th }}$ centuries usually included faculties of law and medicine.

Why should the Latin Church want the training of lawyers and doctors also to be within Church-controlled institutions rather than outside? There are at least three reasons:

1. It would ensure that the leading practitioners of law and medicine, the other main learned professions, fully understood Christian teachings and would practice within a framework of Christian teaching.

2. The Latin Church wanted influence over not only the political life of Western Christendom but also over the personal and professional lives of the Western Christians. It did not want independent colleges of medicine and law challenging its rulings as that could affect its theocratic authority. 
3. The Church saw the control of all education as being an integral part of its remit. It wanted to be in a position to be able to rule on what was true and what was untrue in all the main areas of human life.

But why should the leading learned professions of medicine and law wish to align themselves with the education provided by the Church? There are at least three reasons for this too:

1. The professions of law and medicine were based on bodies of received knowledge and locating their education within institutions sanctified by God gave status and authority to the these teachings and their practitioners.

2. The Latin Church was responsible for nearly all the primary and secondary education on which any professional education would depend.

3. As the theocratic power of the Latin Church grew, it made pragmatic sense for these learned professions to locate themselves within the institutional power of the Church rather than outside it.

Gradually a pattern emerged whereby universities comprised a 'lower' faculty of Arts (based on the 'practical arts' of the trivium and quadrivium and study of scriptural texts) and 'higher' faculties of law, medicine and philosophy (Cobban, 1975). Most students in the medieval university would enter the Church. The higher faculties of the law, medicine and philosophy provided more specialised education for those aiming for careers in the worlds of law, medicine and teaching.

Most students in the early universities did not complete their degrees and receive the LD (licentia docendi) i.e. the license to teach. They learned enough to serve the Church as a priest or in some other clerical capacity. For the most part, it was only those whose ambitions extended to teaching aspiring clerics who would continue to complete the full course of studies leading to the LD.

In summary, most of the students educated in the medieval university would go on to serve the Latin Church in some capacity or other and the medieval university provided an education directed to that end. It also provided preparation for those who aspired to leading positions in the main learned professions of the Middle Ages and in the emergent theocracy of the medieval world. These too were closely related to the Latin Church.

\subsection{The early modern university (from about 1500 to the early $19^{\text {th }}$ century)}

By the late Middle Ages the university 'project' had lost its momentum. There are many reasons for this, including corruption in the Latin Church itself that was increasingly apparent in the $14^{\text {th }}$ and $15^{\text {th }}$ centuries. The goal of providing a higher education that would prepare people for service in the Latin Church therefore became less compelling 
and certainly less uplifting. In these later years of the Middle Ages 'Service to the Church' was a less inspiring vision for universities. It was also a less inspiring vocation for talented young men. Consequently, student numbers fell and recruitment became more difficult, which resulted in financial difficulties for many universities. Financial problems in turn led to other problems. Green (1974) writes of Oxford in the late medieval period:

"In the fifteenth century the university entered into... a period of contraction. Its numbers apparently fell from 1,500 to 1000; only 27 men took the masters' degree in 1456-7. Contemporary letters complained of the shortage of students, teachers and endowments...". "Once, the university exclaimed somewhat rhetorically in 1430, 'she was famous in the world: students flooded to her from every nation: then she abounded with men learned in every art and science; her schools were not dilapidated nor her inns empty'. The university it was urged in a letter to the Duke of Gloucester, pleading for his patronage, 'is reduced to the greatest misery. Lectures have ceased and a complete ruin of education is imminent." (Green, 1974, 31).

The fall in student numbers led to a re-assessment of the priorities of universities. Instead of focusing on the provision of an educated clergy for the Latin Church, it widened its remit to that of providing an education for those who would enter newly emerging professions of the Renaissance and the early modern state. Increasingly, the universities of Europe sought also to offer a higher education for the sons of the wealthy in the new nation states of Europe. In order to attract the sons of those of affluence and noble birth the university curriculum was extended to reflect the growing interest in the Italian Renaissance and humanistic studies (Grendler, 2002).

This need to recruit students and generate fee income shifted the mission of universities in a more student-centred direction. The shift was from service to the Latin Church towards advancement of the students themselves and an important part of this was preparation for a wider range of employments after university (Kearney, 1970). The European University became more open to emerging developments within Europe including the Renaissance, the growth of the nation state and the growth of literacy. These developments offered new learned professions and hence new opportunities for universities.

The Renaissance opened up a range of new occupations and increased opportunities within some existing professions, including those of archivists, antiquarians, librarians, curators and personal assistants to those involved in the intellectual revolution in Europe that the Renaissance represented. This provided the impetus for the adoption of classical studies within the university that became such an important part of university education for centuries to come (Grendler, 2004).

The rise of the nation state in Europe also created new forms of employment for literate professionals. Larger political units created the need for administrators, diplomats and other civil servants. An indication of the growing role of university graduates in governing the new nation state can be found in their increasing numbers in the House of Commons. In 1563 only 67 had a university education and in 1593, only three decades later, the 
number had risen to 160 (Curtis, 1959, 59). This would also appear to have been the time that politics became, for the most part, a graduate profession.

The growth of literacy in Europe in the early modern period also created a rising demand for teachers, a demand which was satisfied by an increasing proportion of new graduates.

With the aim of attracting income from student fees, the post-medieval universities also sought to attract the sons of the well-heeled and well-connected; the vocation of many of these students would be that of gentleman or even noblemen.

In summary, the Renaissance, the rise of the nation state and the growth of literacy gave rise to a range of new literate professions and the focus of universities shifted from service to the Latin Church towards preparation of students for these new graduate professions. Consequently, a university education emerged, based on classical studies and the studia humanitatis, that sought to enable students to tell right from wrong morally, intellectually, socially and aesthetically. It aspired to produce Godly gentlemen who could be a credit to any of the literate professions.

\subsection{Rise of the Humboldtian University}

By the start of the $19^{\text {th }}$ century the Western University had again lost its momentum. It had largely failed to absorb the new ways of knowing and new knowledge of the $17^{\text {th }}$ and $18^{\text {th }}$ centuries. For example, the scientific revolution of the $17^{\text {th }}$ century and the new thinking of the Enlightenment of the $18^{\text {th }}$ century made little impact on the curriculum of a university education at that time.

"By the eighteenth century universities everywhere were in the doldrums, confined to the training of priests or pastors, a few civil servants, and those gentry too poor to educate their sons by private tutors and the increasingly popular 'grand tour' of the Continent. ... most universities in eighteenth century Europe were moribund, with idle professors... despised by the intellectuals of the Enlightenment. In England the historian of the Roman empire Edward Gibbon described his student days at Oxford as "the fourteen months the most idle and unprofitable of my whole life," and his teachers, "the monks of Magdalen," as "decent, easy men who supinely enjoyed the gifts of the founder." In Germany civil servants and politicians seriously discussed whether universities did more harm and good and ought to be abolished." (Perkins, 1997, 14-15).

One consequence of the failure of the Western University to keep abreast of the times was its failure to prepare students for professions and occupations related to the new knowledge of the scientific revolution. University graduates were particularly ill-equipped to enter new occupations and professions based on empirical knowledge including those associated with the emergent industrial revolution. It would seem that by this time the large majority of graduates who needed to find employment after university at this time, did so as clerics or teachers.

A way out of the malaise was provided by William Von Humboldt who established 
the university of Berlin with a new mission: the pursuit of knowledge. It was not the role of the Humboldtian university to serve the needs of students but rather it was the role of students as well as the staff of the university to serve the pursuit of knowledge, including empirical knowledge. In Humboldt's own words (in translation):

"At the highest level, the teacher does not exist for the sake of the student: both teacher and student have their justification in the common pursuit of knowledge" (Humboldt, 1970, 243)

Knowledge is pursued in order that it may be found so the goal of the pursuit of knowledge is the discovery of knowledge and that meant research. This was to become the superordinate goal of the university. It was the birth of the research university. With this goal, university education was able to open its doors to the scientific revolution and its main project, the accumulation of new knowledge.

Berlin's lead was followed by other German universities and what became known as the German model was adopted by universities in other countries too (Simpson, 1983). There are at least three reasons:

- There was a large inflow of students to German universities particularly from those wanting to get a training in research who saw science as a vocation or at least as a source of employment.

- German industry was thriving in the latter part of the $19^{\text {th }}$ century and this was attributed, at least in part, to the adoption of research (and especially research into the natural sciences) by the German universities.

- German professors' commitment to research and publication gave them a source of reputation not enjoyed by the university staff in other universities who confined themselves to teaching. This enhanced the esteem of the German universities as well as German academics.

Consequently, the German universities which had been regarded as the most backward in Europe at the end of the $18^{\text {th }}$ century transformed themselves in the course of the $19^{\text {th }}$ century into the universities that were seen as the most successful. In other words, by the start of the $20^{\text {th }}$ century not only were the German universities seen as at the leading edge but also they were the ones that had made most progress. The conclusion was clear: if you wanted to build a successful university you needed to prioritise the pursuit of knowledge.

According to Humboldt, both staff and students exist within the university to serve the advancement of knowledge. It is easy to see the role of university staff in the 'advancement of knowledge'. What was the role of the students in the 'advancement of knowledge'? What sort of higher education could the Humboldtian university develop that would serve the advancement of knowledge? 
The Humboldtian university developed a form of university education in which the main aim was to equip students to contribute to the advancement of knowledge of an academic subject, particularly through the accumulation and dissemination of knowledge and especially through research and teaching.

By the middle decades of the $20^{\text {th }}$ century the Humboldtian revolution in UK universities was largely complete and by that time the majority of UK graduates entered education-based employment upon graduation. When data on the destinations of university graduates was first published in the early 1960s about two-thirds of the graduates remained in the education system after graduation ${ }^{1}$. The large majority of new graduates were engaged in the advancement of knowledge, directly or indirectly, through the accumulation or dissemination of knowledge and they were prepared for this by the sort of education provided by the Humboldtian university.

In summary, it is difficult to escape the conclusion that graduate employment has been a key issue in the development of the Western University in each of its key stages, medieval, early modern and Humboldtian. It is impossible to understand the Western university or its development without appreciating the importance of the employment of its graduates.

The main conclusion of this section is that graduate employment is not a new issue for universities. Vocationalism goes back to the heart of its medieval origins and has a been a leading issue in every stage of the university's development. Concern with graduate employment goes bone-deep within the body of the university.

However, it is clear that the vocationalism of the medieval university was different from the vocationalism of the early modern university and different again from that of the modern university. The main question raised by this review of universities' concern with graduate employment is the issue of change and continuity: what changed and what remained the same?

\section{The nature and form of university approaches to vocationalism}

The last section adopted a chronological perspective; this section offers a thematic perspective. It looks for commonalities in the vocational engagement of the Western university across the stages of its development and it looks for variations.

Most of the university students in the medieval period went on to employment in the Latin Church, mostly as parish priests, and most of the remainder became lawyers, doctors or teachers2. Universities were probably more vocationally-orientated in the Middle Ages than at any other time in their history. It is potentially instructive, therefore, to explore what forms of vocationalism can be discerned in the university at that time.

\footnotetext{
${ }^{1}$ They went on to teaching, research, further academic study, teacher training, other training or education administration.

${ }^{2}$ The distinction between cleric and teacher was less clear in those days when spiritual knowledge had a far higher status than secular knowledge.
} 
The students were initially enrolled in the Faculty of Arts where they studied the words of the Bible (The Vulgate version, i.e. St Jerome's Latin translation) which for many people in the Middle Ages (and later) contained the literal words of God (McGrath, 2001). They also studied other scriptural texts from established sources such as Augustine of Hippo and other Church Fathers for which, from the $13^{\text {th }}$ century, the standard text used in university education was the 4 volumes of the Sentences by Peter Lombard. In addition, they studied the trivium and quadrivium, known as the practical arts. Afterwards, some of the students continued their studies in the higher faculties of medicine, law, theology or philosophy. A medieval university was intended to produce educated clerics, teachers, lawyers and doctors.

It is clear then, that one form that concern with graduate employability took was subject of study. The earliest universities focused on subjects with vocational relevance.

It is also clear that the medieval universities were concerned with vocational skills. This is evident even at the Arts-based foundation level. The so-called 'practical arts', the trivium and quadrivium, were practical because they were skills that could be useful to servants of the Latin Church, particularly parish clergy, which was the destination of most of the graduates of the medieval university.

The trivium (3-part curriculum) comprised grammar, reasoning (dialectic) and rhetoric. This was followed by the quadrivium (4-part curriculum) which comprised arithmetic, geometry, astronomy and music.

All the subjects were of potential value to those destined to serve the Latin Church. Grammar trained the students to speak, read and write Latin - the language of the Bible and the Latin Church more generally in the middle ages. Rhetoric taught them public speaking - essential for priests to communicate with a congregation. Reasoning provided a means of interpreting the word of God to members of the congregation in the light of changing circumstances.

As for the quadrivium, arithmetic was needed for managing church finances, geometry was needed for those concerned with establishing and maintaining churches (for architecture, surveying and calculating measurements), astronomy was needed for calculating important religious dates such as Easter and music played an important part in the ritual of the church.

The other great practical skill acquired by medieval students was a facility with Latin. This was clearly of value to aspiring priest as the Holy Bible was in Latin and the services of the Latin Church were in Latin. It was also of value to those students who had other vocational aspirations.

If knowledge is power then Latin was the key to that power. It was the key to the power of the Church, Roman Law, all the learned professions, the academy and communicating with educated people across Europe. This is clear from Waquet's authoritative work on Latin: or, the empire of a sign:

"Over the centuries it (Latin) had acquired real claims to universality by being the language of three great powers, political, religious and intellectual, which had ruled over immense territories: the Roman Empire, the Church, the Republic of Letters" (Waquet, 2001, 258) 
In addition to vocational knowledge and vocational skills the medieval university sought to inculcate values and attitudes that were appropriate to servants of the Church, including faith, piety and obedience to the Latin Church. These values and attitudes would also be sought in doctors, lawyers and teachers in the theocracy that was the Europe in the high middle ages.

In summary, three distinct elements can be discerned within the vocationalism of the medieval university: (1) the subjects available to study (2) skills for employment and (3) vocationally relevant values and attitudes i.e. values and attitudes that would best serve the most likely vocation or calling of university graduates. This tripartite classification, apparent in the experience of the university in its earliest and most vocationallyorientated, period, offers a framework for exploring vocationalism in universities in subsequent periods.

The framework can be used to explore vocationalism in the next stage of the Western university, the Renaissance and early modern university that held sway from the late $15^{\text {th }}$ century until the early $19^{\text {th }}$ century.

\subsection{Renaissance and early modern university}

We've seen that the Western University experienced a crisis in the later middle ages because of its close association with the Latin Church at a time when the Latin Church was in decline. Its moral, spiritual, political and intellectual authority fell steeply in the later Middle Ages. Universities consequently experienced great difficulty in recruiting students who wished to serve the church, which had been the majority of its students.

Universities responded to the crisis by recruiting students for a broader range of destinations. Using the framework of vocational engagement developed above, we can predict change in the range of subjects, change in the skills developed and change in the values and attitudes they tried to inculcate.

After the medieval period, fewer students aspired to careers in the Latin Church and more students looked to a greater variety of employment after university, including archivists, antiquarians, librarians, curators and personal assistants to those involved in the intellectual revolution in Europe that the Renaissance represented and the emergent nation state created employment for graduates as administrators, diplomats and other civil servants and more politicians. And the growth of literacy in Europe in the early modern period also created a rising demand for teachers, a career pursued by an increasing proportion of new graduates. The word 'clerk' for employment that required literacy betrays the clerical source of that literacy ${ }^{3}$. In other words, there was a diversification in the range of destinations of students after university.

At that time, all the students at each university studied a similar curriculum so that diversification of student destinations presented a problem to the universities. The so-

\footnotetext{
${ }^{3}$ The original derivation seems to have emerged in medieval courts where writing was entrusted to clerics because they could read and write and because, as men of the Church, they could be trusted to record decisions truthfully.
} 
lution of the universities in the early modern period was to offer a university education that would prepare students to become 'godly gentlemen' who could grace any profession. The Church-based subject-matter of the curriculum contracted somewhat and there was a greater emphasis on breadth of study. This was achieved by greater attention to classical studies, underpinned by the Renaissance of the $15^{\text {th }}$ and $16^{\text {th }}$ centuries. It included knowledge of the classical era of Greece and Rome and knowledge from that classical period and it led to a shift in values towards humanism and the aesthetic arts. University education became more liberal. Different universities differentiated themselves by the focus of their curriculum. Thus, for example, in England, mathematics became a feature of the University of Cambridge and the emphasis on classical studies was particularly strong at the University of Oxford.

Is it possible to discern also the emergence of new vocationalskillsin the university of the early modern period? Latin retained its importance as the dominant language of the learned professions. The ability to write well became more important as more graduates went on to become clerks rather than clerics. The new professions placed increasing emphasis on written communication and so this acquired a new significance in universities. And there was increasing emphasis on the development of social skills which were particularly important in some careers,such as diplomacy. This was reflected in the sentiment, 'Manners makyth man' which was enshrined as the motto of New College, Oxford. It would not be unreasonable to describe universities of the early modern period as 'finishing schools' for the sons of the well-heeled and as a preparation for social advancement.

The values and attitudes developed by the universities of the high middle ages gave way to new values and attitudes appropriate to a godly gentleman employed in one of the new professions of the early modern period. Whereas the medieval university had encouraged faith and the pursuit of such knowledge as was sanctified by the Latin Church, the early modern university valued curiosity and knowledge for its own sake. This was a very significant departure as curiosity had been frowned up by the Latin Church. No less a figure than Augustine of Hippo, whose words carried much weight in the Medieval Latin Church, had spoken of curiosity as a 'sin' (Freeman, 2002). It was in the early modern period that the term 'a gentleman and a scholar' first appeared and it was intended as a compliment, a sign of approval and respect.

Discernment of excellence and the pursuit of excellence was emphasised in the early modern university which hoped its graduates would become discerning gentlemen who pursued excellence in whatever profession they progressed to after graduation.

The universities of the Renaissance and the early modern period placed more value on realism in contrast with the medieval university which subscribed to more allegorical perspectives. This is clear in the changing arts and artistic perspectives of the Renaissance and after the Renaissance. Again, this emphasis on realism supported more worldly values.

So the movement from the medieval university to the early modern university saw a movement of values from faith, piety and obedience to new values including curiosity, realism, education for its own sake and the pursuit of excellence. Whereas the former were values appropriate for a priest or member of a learned profession in the theocracy of 
that was Europe in the high middle ages, the latter were more aligned with employment in a range of 'new' professions that attracted more graduates after the Renaissance.

\subsection{The modern university}

The modern university that emerged in Germany in the $19^{\text {th }}$ century was inspired by the ideas of the Minister of Education for Prussia, William Von Humboldt, with his vision of student development based on the pursuit of knowledge. This vision allowed the empirical sciences into university education. It was perhaps not a coincidence that William's brother was the celebrated scientist Alexander Von Humboldt. Until that time, science had played a negligible part in university education (Ashby, 1974). Many university academics studied science and made very significant contributions to the advancement of science but science had had a very limited role in university education per se. The main reason for this was that it was difficult to make a compelling case for its inclusion in the preparation of clerics which still accounted for the destinations of the majority of university students. This again emphasises the importance of vocational preparation in university education at that time.

Humboldt founded Berlin university with his philosophy of university education based on the pursuit of knowledge. The success of Berlin University inspired imitation by other universities across Germany and this, in turn, led to an inflow of students from abroad, particularly from the USA, who would get a training in scientific research which would prepare them for careers in science 4 .

The goal of science is the pursuit of the knowledge and the way that science accumulates knowledge is by increasing specialisation. The inevitable result of the entry of science into university education, therefore, was the development of subject specialisation. The common university curriculum that still characterised each university in the $18^{\text {th }}$ century was eroded in the $19^{\text {th }}$ century by the emergence of the modern university in which science and subject specialisation became characteristic features. The number of universities expanded considerably during the $19^{\text {th }}$ century and early $20^{\text {th }}$ century and this was accompanied by a reduction in the percentage of students entering the Church after graduation and a rise in the percentage going into teaching.

The success of the German economy, including the growth of its military strength, in the second half of the $19^{\text {th }}$ century was attributed, at least in part, to the adoption of research, the exploitation of scientific knowledge and the development of education generally. This encouraged governments in other countries to support higher education and it was the scientific and vocational subjects that were supported most.

In summary, the university education offered by the modern university in the $20^{\text {th }}$ century differed greatly from the early modern university of the $18^{\text {th }}$ century in terms of its vocational orientation. Most important was the proliferation of subjects within each

\footnotetext{
${ }^{4}$ The scientific revolution is commonly regarded as a phenomenon of the $17^{\text {th }}$ century. It was not until the $19^{\text {th }}$ century that science became professionalised. Until the $19^{\text {th }}$ century it was known as 'natural philosophy' and was largely the province of independent enquiry by affluent individuals, often as a hobby. By the end of the $19^{\text {th }}$ century the hobby of 'natural philosophy' had become the profession of 'science'.
} 
university, the preparation for students for careers in the sciences and the development of subjects which, it was believed, could contribute to the advancement of the material wellbeing of national economies, though this relationship of capitalism to wellbeing has been a subject critical analysis throughout the twentieth century (Weber, 1905; Boltanski and Chiapello, 2005).

The curriculum of the early modern university emphasised the classical studies within a religious context and all the students at a particular university studied a similar university curriculum. By contrast, the modern university brought significant changes to the university curriculum at the subject level. First, the admission of science as a recognised field of university education meant that science became recognised as an appropriate training for a career in science and technology. Second, the entry of science into university education brought with it subject specialisation, so the range of subjects that could be studied started to proliferate, a process that has not ceased. Third, the entry of science elevated the esteem of up-to-date knowledge. The university of the Renaissance and early modern period had esteemed that which was 'best' in knowledge and was prepared to trawl the accumulated knowledge of the previous three thousand years to find it, discovering most of it in the classical periods of Greece and Rome. Because the core goal of the scientific project is the accumulation of knowledge the emphasis shifted to the latest knowledge. University education became a vehicle for disseminating the fruits of the quest for new knowledge.

What, if any, was the impact of the emergence of the modern university on the vocational skills developed by a university education? There were at least three. First, the modern university placed increasing emphasis on critical thinking. It reinterpreted the 'liberal' education, much valued in the Renaissance and early modern university, to mean education that 'liberates', and then developed critical thinking as a form of thinking that could liberate knowledge from the shackles of authority, error and deception. A modern university education became one focused on the latest knowledge of a recognised field of study together with the ability to think critically. In the modern university 'understanding' a subject was realised by the application of critical thinking skills to up-to-date knowledge in that subject. Critical thinking skills involve the ability to test assumptions, assertions, evidence and conclusions. Critical thinking was the skill most valued by the modern university and it was valued by employers. One definition of a 'graduate job' is as that it required the application of critical thinking skills (Bourner et al., 2011). By the mid- $20^{\text {th }}$ century critical thinking had become the hallmark of a graduate education. According to Sir Douglas Hague, chair of the Economic and Social Research Council for much of the 1980s:

"Academics must believe that acquiring the ability to test ideas and evidence is the primary benefit of a university education." (Hague, 1991, 64)

Second, the modern university placed increased emphasis on written communication.It is not a coincidence that this is the medium employed in the dissemination of new knowledge, particularly through academic journals and books. It was also a skill that 
was very relevant vocationally to an increasingly literate, or at least, text-based, age. Most graduate jobs involved written communication. In the modern university, oral examinations were largely replaced by written examinations.

Third, the modern university placed increasing importance on subject-specific skills and as most of the new subjects were vocationally relevant, so too were the subjectspecific skills. Thus, for example, chemists acquired laboratory skills, physicists acquired mathematical skills, economists acquired statistical skills and so on.

Using the framework developed above to explore vocationalism in universities we now ask if any new vocational values or attitudes emerged with the transition into the modern university? Once again, it was the admission of science that accounts for the main changes. Science brought with it a questioning attitude which valued scepticism. This served all those graduate employments that involved the production, dissemination or application of new knowledge. More and more graduates became employed in teaching and other parts of the education system until by the high years of the $20^{\text {th }}$ century they accounted for the destinations of about two-thirds of all students after graduation (Bourner and Rospigliosi, 2008). Knowledge itself became more highly valued in the modern university, particularly the accumulation of knowledge, until it became the defining feature of a university. This too was elevated by the admission of science into university education because the meta-goal of science is the accumulation of knowledge. The vocational significance of this in what became known as the 'knowledge economy' need not be laboured.

And alongside enhanced respect for a sceptical attitude, a questioning stance and knowledge itself came the greater regard for the value of impartiality. 'Rhetoric' which had played an important role in the university education offered by the medieval, renaissance and early modern universities failed, for the most part, to make the transition to the modern university. The ability to make a case for something fell relative to the ability to test a case (see the quote from Hague above). According to Karl Popper: "Science can be said to be largely the result of criticism of the critical examination and selection of conjectures, of thought contents." (Popper, 1978, 160).

'Partiality' became seen as an impediment to the pursuit of truth and the advancement of knowledge. Members of learned professions were increasingly expected to be able to exercise independent judgement and in some learned professions their role was extended to include functions associated with arbitration, consulting, mediation and expert witness.

The main conclusion of this section is that the model of vocationalism developed from the examination of the medieval university has helped to reveal the vocationalism of the education offered by the western university in its succeeding stages. In each stage of the development of the western university education it is possible to discern vocational subjects, the development of vocational skills and encouragement of vocational values and attitudes.

The following table summarises the conclusions: 
Table 1: Summary of conclusions

\begin{tabular}{|c|c|c|c|}
\hline & Stage 1 & Stage 2 & Stage 3 \\
\hline Epochs & $\begin{array}{l}\text { The medieval uni- } \\
\text { versity }\end{array}$ & $\begin{array}{l}\text { Renaissance and } \\
\text { early modern uni- } \\
\text { versity }\end{array}$ & $\begin{array}{l}\text { The modern uni- } \\
\text { versity }\end{array}$ \\
\hline \multirow[t]{3}{*}{$\begin{array}{l}\text { Vocationally } \\
\text { relevant sub- } \\
\text { jects }\end{array}$} & $\begin{array}{l}\text { The Words of } \\
\text { God (as recorded } \\
\text { in the Vulgate } \\
\text { Bible) }\end{array}$ & Classical studies & $\begin{array}{l}\text { Science and tech- } \\
\text { nology }\end{array}$ \\
\hline & $\begin{array}{l}\text { The words of } \\
\text { Fathers of Latin } \\
\text { Church (as } \\
\text { recorded in Pe- } \\
\text { ter Lombards } \\
\text { Sentences) }\end{array}$ & $\begin{array}{l}\text { Widening of the } \\
\text { curriculum }\end{array}$ & $\begin{array}{l}\text { Subject speciali- } \\
\text { sation within uni- } \\
\text { versity education }\end{array}$ \\
\hline & $\begin{array}{l}\text { Law, medicine, } \\
\text { philosophy and } \\
\text { theology (in the } \\
\text { higher faculties) }\end{array}$ & Humanities & $\begin{array}{l}\text { New knowledge, } \\
\text { at least up-to- } \\
\text { date knowledge }\end{array}$ \\
\hline \multirow[t]{3}{*}{$\begin{array}{l}\text { Vocationally } \\
\text { relevant skills }\end{array}$} & Latin & Latin & $\begin{array}{l}\text { Critical thinking } \\
\text { skills that enable } \\
\text { a student to } \\
\text { test ideas and } \\
\text { evidence }\end{array}$ \\
\hline & $\begin{array}{l}\text { Trivium } \text { (gram- } \\
\text { mar, dialecti- } \\
\text { cal reasoning } \\
\text { rhetoric) }\end{array}$ & $\begin{array}{l}\text { Ability to speak } \\
\text { well and write } \\
\text { well }\end{array}$ & $\begin{array}{l}\text { Skills of written } \\
\text { communication }\end{array}$ \\
\hline & $\begin{array}{l}\text { Quadrivium } \\
\text { (arithmetic, } \\
\text { geometry, as- } \\
\text { tronomy } \\
\text { music) }\end{array}$ & $\begin{array}{l}\text { Social skills } \\
\text { (Manners makyth } \\
\text { man') }\end{array}$ & $\begin{array}{l}\text { Subject-specific } \\
\text { skills }\end{array}$ \\
\hline \multirow{3}{*}{$\begin{array}{l}\text { Vocationally } \\
\text { relevant values } \\
\text { and attitudes }\end{array}$} & Piety & $\begin{array}{l}\text { Pursuit of excel- } \\
\text { lence }\end{array}$ & $\begin{array}{l}\text { Sceptical/ ques- } \\
\text { tioning attitude }\end{array}$ \\
\hline & $\begin{array}{l}\text { Obedience to the } \\
\text { Latin Church }\end{array}$ & Curiosity & $\begin{array}{l}\text { Accumulation of } \\
\text { knowledge }\end{array}$ \\
\hline & Faith & Realism & $\begin{array}{l}\text { Impartiality and } \\
\text { objectivity }\end{array}$ \\
\hline
\end{tabular}




\section{Discussion}

This section discusses some assumptions or issues that have emerged in the paper so far. These include (1) the categorization of the stages of the development of the western university used in the paper, (2) the proliferation of subjects available within a university education, (3) 'moral panic' surrounding vocationalism in university education and (4) historicism as a guide to future vocationalism in university education.

\subsection{Stages of development of the university}

This paper has worked within a 'stages' framework of the development of the western university: medieval, early modern and 'modern'. Other categorizations of the development of the Western University are of course possible. For example, it could be contended that the Napoleonic university with its emphasis on preparation of young men for professional employment by the State constituted an additional stage of development. Whilst it is true that the Napoleonic University contributed to the development of the Western university that exists today, we contend that its contribution is relatively small and it too had a vocational impetus. Similar responses can be made to the other challenges of omission that can be made to the tripartite classification we have used.

We would also contend that this tripartite classification is not one we have developed to support the conclusions we draw in this paper, but rather it is the consensus model of the main developmental stages of the western university. This was, for example, the categorization used by the Standing Conference of Rectors, Presidents and ViceChancellors of the European Universities, now European University Association (EUA) for their monumentalHistory of the European University in Europe (Ridder-Symoens, 1992; Ridder-Symoens, 1996; Ruegg, 2004).

For us it is significant that the consensus view of the stages of the development of the university appears to be based on changes in the vocational engagement of universities.

\subsection{Specialisation within university education and proliferation of subjects}

Until the $19^{\text {th }}$ century, for the most part, all the students at the undergraduate level studied a common curriculum. There was some variation between universities but little variation within each university. This had its origins in the curriculum of the medieval where all students were admitted into the faculty of Arts (referring to the practical arts of the trivium and quadrivium) and only when they graduated could they be admitted to the 'higher' faculties of law, medicine, theology or philosophy.

We have argued that subject specialisation took off in the $19^{\text {th }}$ century after the admission of science into university education. The goal of science is the pursuit of the knowledge and the way that science accumulates knowledge is by increasing specialisation. The inevitable result of the entry of science into university education was the emergence of subject specialisation. The common university curriculum that still characterised each university in the $18^{\text {th }}$ century was eroded in the $19^{\text {th }}$ century by the 
development of the modern university in which a university education in science and subject specialisation became established features. As the number of universities expanded during the $19^{\text {th }}$ century and early $20^{\text {th }}$ century the percentage of students entering the Church after graduation declined with a corresponding rise in the percentage going into teaching. During the enlightenment of the $18^{\text {th }}$ century and the industrial revolution of the $19^{\text {th }}$, the value placed in secular knowledge rose relative to the value placed on spiritual knowledge and teachers were needed in a wider range of subjects.

The admission of science into university education opened the door to the proliferation of subjects within university education. We are not suggesting that this was the only factor contributing to that proliferation. We are suggesting, however, that it needed something exceptional to undermine the powerful convention of a common curriculum at each university, which had persisted since the birth of the university in the Middle Ages and still endured in most universities at start of the $19^{\text {th }}$ century. And we are suggesting that the admission of science was that something. After that, the door was open for other forces favouring subject specialisation, and hence subject proliferation. These forces included (1) the desire of government to secure the supply of graduates in fields of particular relevance to national well-being (2) the desire of professional associations to become recognised as 'learned' professions by becoming studied at university and (3) the desire of universities to offer subjects that would attract students and, moreover, attract the 'best' students.

The proximate goal of science was to enlarge the pool of knowledge from which all could freely draw. Behind that, was the meta-goal of improving the material well-being of people. After science had gained admission to the university and opened the door to subject specialization, other subject specialisms were able to pass through. Various social sciences claimed that they offered the prospect of enhanced social wellbeing. Various arts subjects and humanities also offered the prospect of enhanced social and personal well-being. The principle of subject specialization allowed entry to a growing range of subjects that could also make a case for contributing to improving social, personal, technological or economic well-being. And many of these subjects, such as business and management studies, were explicitly vocational.

The admission of science and technology into university education generated increasing interest by government in the potential role of universities as sources of national wellbeing which led to increasing funding from government and increasing government intervention. Governments became interested in the knowledge produced by universities, particularly knowledge in the fields of science and technology, and in the supply of graduates in fields regarded as significant to support the material well-being of the country. Governments became increasingly interested, also, in universities supplying highly qualified 'manpower' as a source of national wellbeing and international advantage. Governments were increasingly keen to support the supply of graduates in fields of study with much vocational relevance, such as scientists, engineers, doctors, teachers, mathematicians, managers and later computer specialists. Government support for increasing the supply of graduates in fields that could increase national well-being invariably meant support for the inclusion and expansion of subjects that were vocationally relevant.

Law and medicine were viewed as learned professions at the time of the birth of the 
Western university in the Middle Ages. Subsequently, other learned professions emerged but were unable to gain admission to university education due to the convention of a common syllabus for all the undergraduates in each university. It was only after that convention had been undermined by the admission of science into university education that the more recent learned professions could gain entry. It is no coincidence that the USA was both an early adopter of the Humboldtian university model that admitted science and a leader in offering courses of study in professional studies like business and management, journalism and accountancy.

Again, once the doorway to subject proliferation had been opened by the admission of science, universities took the opportunity to offer degrees in subjects that would recruit more students. The development of a pecking order of universities meant that universities competed with each other to obtain the 'best' students. The pecking order was related to funding and prestige amongst universities. One strategy in this competition was to offer degrees in subjects that would attract students who wanted a vocationally relevant education.

The conclusion of this section is that the admission of science into university education provided a vocationally relevant higher education for students who wanted a career in the developing field of science. And it was the admission of science into university education that opened the door to other forces that would widen the range of other vocational subjects of study at university.

\section{3 'Moral Panic' and vocationalism in university education}

The belief that university education has traditionally been about engaging students in the pursuit of knowledge for its own sake and this is now being compromised by vocational concerns about making a living, securing advantageous employment and making money, has caused a strong reaction by some academics who see in this a decline from the high ideals of university education. 'Moral panic' is the term given to extreme social reaction to a belief that the moral conditions of society, or some aspect of society, is declining at a rapid rate. Moreover, for those for whom university education is the main rationale for universitie 5 , this has caused concern about the moral deterioration of the university itself.

The opening paragraph of this paper provides an explicit statement of this belief and the body of this paper has shown that this story about corruption of traditional university education by vocationalism does not hold water. A different, and contrasting, story can be told about the vocationalism in university education that is more uplifting, as follows. University academics have always been concerned about the wellbeing of their students, including providing a university education that enhances their life-chances. Evidence of high graduate unemployment causes university academics to be concerned about the nature of the education they are providing and that concern leads to change in university education. According to this alternative story the concern of university academics with

\footnotetext{
${ }^{5}$ Including, for example, those who subscribe to Cardinal Newman's idea of a university (Newman, 1959).
} 
the employment and employability of graduates is an important element of studentcentred HE about which academic staff in universities can feel proud. Moreover, this is a story that better fits the facts.

\subsection{Historicism and vocationalism in university education}

In this paper we have shown that universities have, traditionally, been concerned with the vocational consequences of university education and this concern has been expressed by offering subjects with vocational relevance, developing vocationally relevant skills and cultivating vocationally relevant attitudes.

One significant value of placing an issue in its historical context is that it can help to identify how best to address the issue currently and in the future. In this case, for example, it would suggest that much of the anxiety and moral panic about the loss of a purer' form of university education is unnecessary as it is based on a myth.

On the other hand, the past is not always a good guide to the future; discontinuities exist, lessons are learned from past experience that can change the future and projections based on the past can fail. What worked well in the past will not necessarily work in the future so success can be a poor teacher.

In recent decades graduate unemployment has risen to historically high levels, a high proportion of graduates have been employed in so-called 'non-graduate jobs' and a high percentage have been employed in temporary, short-term or part-time employment. Moreover, offering university education with more vocational courses, skills and attitudes, the time-honoured solutions, has not been effective (Bourner et al., 2011).

What has gone wrong? Why have these tried and tested approaches failed? How is the past different from the present and the future? There are two main issues: (1) in the past, universities were elite institutions in the sense that a relatively small percentage of people of each generation acquired a university education, (2) the rate of change in the world is accelerating. These two factors mean that the graduate employment in the future will be unlike graduate employment in the past.

As the age-participation rate has risen over recent decades a decreasing proportion of new graduates has gone into destinations for which subject knowledge of their first degree is a prerequisite. A study by Bourner and Rospigliosi (2008) of the changes in the pattern of the first destinations of university graduates since destinations data were first published found that in the 1960s about six out of ten graduates remained within the education system after graduation, going on to teaching, research, further academic study, teacher training, other training or education administration. Now that ratio is down to about three out of ten. The main reason for this is the huge rise in the HE age-participation rate over that period. Most graduates now find jobs in other sectors, including industry, wholesale/retail, financial services, other commerce and public services other than education. Moreover, most employers in these other sectors are not much concerned about whether the academic knowledge of the students they recruit is up to date. Indeed, most employers of graduates are not even much concerned about the degree subject at all: most vacancies (around two-thirds in some years) for graduates each year ask for graduates in any subject. 
"Of course, there are many students who find employment in an area directly related to their degree courses. Engineers become engineers, medical students become physicians, some linguists become interpreters and translators But it is also true that every year between 40 percent and 70 percent of all graduate vacancies ask for a degree in any discipline because the knowledge content of the student's degree is immaterial to the position. " (Roberts, 2006, 12)

It would seem that most graduate employers are less concerned with what graduates have learned at university than with what they will learn in the future if and when they engage them as employees. Consequently, Bourner et al. (2011) concluded that the main reason for the so-called 'graduate premium' is that graduates have an enhanced capacity, and disposition, for learning. According to Rospigliosi et al. (2014) this enhanced capacity is partly what secured their places at university (as 'signalling' theory predicts) and is partly developed by university education (as 'human capital' theory predicts).

Some graduates, of course, remain within the education system after graduation. Others acquire jobs that increasingly involve the production, distribution and/or application of knowledge, but not necessarily in the subject of their degree studies. There are probably very few graduates who find jobs that do not involve the production of new knowledge at some point(s) in their graduate careers. From this perspective, the development of student capacity, and disposition, to learn, can make the students more attractive to employers of graduates and better prepared for graduate employment itself.

Another major factor in the shift towards the vocational value of the capacity to learn is the accelerating pace of change. While there is not space here to fully develop the case (see for example, Kurzweil, 2006; Colvile, 2016) here are just two pieces of evidence.

First, the number of academic journals that publish new knowledge is rising at an accelerating rate. In 1665 there was only one scientific journal published in the whole world, The Philosophical Transactions of the Royal Society. Two hundred years later, in 1865, there were already over a thousand journals. And one hundred years after that, in 1965, the number had risen to one hundred thousand.

Second, practical knowledge is accumulating at an increasing rate outside of the scholarly journals (Nowotny et al., 2003). Arguably, vocationalism in universities has supported the admission of new forms of knowledge into the university, including, for example, practitioner-centred research and the resulting practitioner-based knowledge (Schön, 1983; Jarvis, 1999). A measure of the growth of practical knowledge is the number of patents granted. An increase in the number of patents granted is a plausible index of growth of practical knowledge produced outside of the universities. This data indicates that the number of patents granted worldwide is growing at an increasing rate (Strauss, 2008).

These examples, understate the growth in practical knowledge i.e. the sort of knowledge that fuels change (Ridley, 2010). Most of our growing knowledge about the internet, has not been recorded in academic journals - for example the development of the web by Tim Berners-Lee (Naughton, 2000). 
The conclusion that most employers are less concerned with the knowledge and skills they have acquired on their degree courses than their capacity, and disposition, to learn in their future employment is known as the 'new vocationalism'. It explains the otherwise puzzling fact that the majority of graduate job vacancy advertisements are open to graduates of any subject discipline and it is consistent with empirical data on graduate employment (Bourner et al., 2011; Bourner et al., 2014; Rospigliosi et al., 2014).

An important implication of this conclusion is that developing students' capacity and disposition to learn supports the subject-centred part of university education as well as the student-centred part.

\section{Conclusions}

In this paper we have looked at the belief that vocationalism in university education is a recent development. We believe we have shown that, on the contrary, the story that university education used to be about engaging students in the pursuit of knowledge (until its corruption, in relatively recent times, by baser concerns with vocationalism), is a myth. We have looked at the evidence of university engagement with vocationalism in each of the main stages in the development of the Western University since its emergence in the middle ages and found that vocationalism has played a major role in each of those stages. It has a pedigree that goes back to the birth of the western university.

The paper has also used the university experience with vocationalism to develop a taxonomy of university vocational engagement. The history of vocationalism in universities can be disaggregated into vocational subjects, vocational skills, and vocational attitudes. Such a framework can be used to enhance understanding of vocationalism in university education and the history of university education more generally.

Recent attempts to address the problem of current graduate unemployment within this framework, however, have been found wanting. We suggest the reason for this is a combination of greater participation in higher education and accelerating change in the world (Bourner et al., 2011). Greater participation associated with the arrival of mass $\mathrm{HE}$, means that traditional graduate professions, including teaching, cannot absorb all the graduates. And accelerating change means that most employers are less concerned with the knowledge and skills that students acquire while at university and more concerned with their capacity, and disposition, to learn after entering their employment.

\subsection{Implications}

There has been a certain amount of 'moral panic' within universities about sullying university education with vocationalism. One implication of this paper is that such moral panic is unjustified. Vocationalism in university education is as old as the western university itself. Universities' concern about the employment and employability of graduates can be viewed as an important element of student-centred HE about which academic staff in universities can feel proud. This is, moreover, an alternative story about vocationalism in universities that better fits the facts. 
A second implication is that there is value in taking a longer perspective on current problems faced by universities. It is not sufficient to look at such issues on the basis of the values and beliefs expressed in the practices of universities within living memory. Even a very senior academic with 40 years of working experience in universities will have witnessed no more than 5 per cent of the history of the Western university with nothing to suggest this is a typical 5 per cent and much to suggest it is not. Universities are venerable institutions and that means that placing current issues in historical context means taking a very long view indeed.

However, what worked in the past will not necessarily work in the future. This is another lesson from the history of vocationalism in university education a shift to even greater focus on vocational subject-matter, vocational skills and vocational attitudes is unlikely to have a significant impact on graduate employment. It worked in the past because the age-participation ratio was low and the relative slowness of the rate of change in the world meant that what was taught on a university degree would remain current for a long while. The changing focus of the modern university on up-to-date knowledge has exacerbated this problem of continuing currency. As change accelerates, the currency of a given piece of up-to-date knowledge erodes more rapidly. This does not mean that it is not worth exploring the historical context of current problems but only that they need to be put into the context of accelerating change.

Vocationalism in university education and pursuit of knowledge for its own sake are often seen as countervailing forces. The sort of vocationalism that can be traced back to the medieval university, including vocationally-relevant subject-matter, skills and vocationally-relevant attitudes, does seem to be the enemy of university education aimed at the pursuit of knowledge for its own sake. However, vocationalism centred on developing students' capacity and disposition to learn, supports both graduate employability and contributes to the accumulation of knowledge. All new knowledge starts with an individual learning something new. Consequently, the conflict between vocationalism and subject-centred university education can be reconciled by increasing the emphasis in university education on developing students' capacity, and disposition, to learn.

\subsection{Further work}

This paper has looked at the deep history of vocationalism in university education, starting with the birth of the western university in the middle ages and ending just before the steep rise in graduate unemployment in the early 1980s. The narrative becomes much denser at that point and we are still much affected by events starting then. It would, therefore, be worthwhile exploring the more recent history of vocationalism in university education, say, 1980 to 2000. Although this period is more well-known, it is likely that it has already accumulated its own myths. It would also be worth putting other issues of current concern in universities into historical context, such as studentcommunity engagement, the belief that standards in university education are falling and the popular story of university decline.

There is much we can learn from the history of vocationalism in university education, including the fact that it has a pedigree that goes back to the birth of the western 
university in the middle ages. However, there is a danger in applying lessons from the past uncritically to the future as contexts change. But there is no value at all in applying the lessons of myth, bad history, to the future. And the story that vocationalism in university education is a recent development is bad history, a source of bad lessons and prescription for bad policy. 


\section{References}

Ashby, E. (1974). Adapting Universities to a Technological Society. London: JosseyBass.

Bailey, M. \& Freedman, D. (2011). The Assault on Universities: A Manifesto for resistance, London, Pluto Press.

Bartlett, R. (1993). The Making of Europe: Conquest, Colonization and Cultural Change, 950-1350, London: Penguin.

Bhaskar, R. (2010). Reclaiming reality: A critical introduction to contemporary philosophy. Taylor \& Francis.

Boltanski, L. \& Chiapello, E. (2005). The new spirit of capitalism. International Journal of Politics, Culture, and Society, 18(3), 161-188.

Bourner, T. \& Rospigliosi, A. (2008). 'Forty years on: long term change in the first destinations of graduates', Higher Education Review, Vol. 41. No. 1, p. 36-59.

Bourner, T., Greener, S. \& Rospigliosi, A. (2011). 'Graduate employability and the propensity to learn in employment: a new vocationalism', Higher Education Review, Vol. 43, No. 3 p. 5-30.

Bourner, T., Heath, L. \& Rospigliosi, A. (2014). Research as a transferable skill in higher education Higher Education Review, 46 (2).

Burnett, C. (1997). The Introduction of Arabic Learning into England; The Panizzi Lectures, 1996. London: The British Library.

Cobban, A. (1975). The Medieval Universities: Their Development and Organisation, London: Methuen.

Collini, S. (2012). What are Universities For? London: Penguin.

Colvile, R. (2016). The Great Acceleration: How the World is Getting Faster, Faster. Bloomsbury Publishing.

Curtis, M. (1959). Oxford and Cambridge in Transition 1558-1642, Oxford.

Freeman, R. (2002). The Closing of the Western Mind, London: Heinemann.

Graham, G. (2002). Universities: The Recovery of an Idea, London: Imprint Academic.

Grendler, P. F. (2002). The universities of the Italian Renaissance. JHU Press.

Grendler, P. F. (2004). The universities of the Renaissance and Reformation. Renaissance Quarterly, 1-42.

Green, V. (1974). A History of Oxford University London: Harper-Collins.

Hague, D. (1991). Beyond Universities: a New Republic of the Intellect, London: Institute of Economic Affairs.

Haskins, C. (2002). The Rise of Universities, Ithaca (USA): Cornell University Press.

Herriot, P. (1984). Down from the ivory tower: Graduates and their jobs. John Wiley \& Sons Inc.

Humboldt, W.V. (1970). On the spirit and organisational framework of intellectual institutions in Berlin. Minerva, 8(2), p. 242-250.

Jarvis, P. (1999). The practitioner-researcher: Developing theory from practice. San Francisco, CA: Jossey-Bass.

Kearney, H. F. (1970). Scholars and Gentlemen: Universities and Society in PreIndustrial Britain, 1500-1700. Cornell University Press. 
Kurzweil, R. (2006). The Singularity is Near, London: Duckworth.

Maskell, D. \& Robinson, I. (2002). The New Idea of a University, Imprint Academic.

McGrath, A. (2001). In the Beginning: the Story of the King James Bible, London: Hodder and Stoughton.

Naughton, J. (2000). A Brief History of the Future: The Origins of the Internet, London: Phoenix Publishing.

Newman, J. H. (1959). The Idea of a University, ed. George, N. Schuster, New York.

Nowotny, H., Scott, P. \& Gibbons, M. (2003). Introduction: Mode 2'Revisited: The New Production of Knowledge. Minerva, 41(3), 179-194.

Pedersen, O. (1997). The First Universities: Studium Generale and the Origins of University Education in Europe, Cambridge: Cambridge University Press.

Perkins, H. (1997). 'History of Universities' in The History of Higher Education (Second Edition) edited by Goodchild, L and Weschler, H, Boston, USA: Pearson.

Popper, K. (1978). Three Worlds The Tanner Lecture on Human Values 1978, University of Michigan.

Ridder-Symoens, H. (1992). Universities in the Middle Ages (Vol. 1 of 'A History of the University in Europe'), Cambridge: Cambridge University Press.

Ridder-Symoens, H. (1996). Universities in Early Modern Europe (1500-1800) (Vol. 2 of 'A History of the University in Europe'), Cambridge: Cambridge University Press.

Ridley, M. (2010). The Rational Optimist, London: Fourth Estate.

Roberts, L. (2006). After you Graduate: Finding and getting work you will enjoy, Berkshire: Open University Press.

Rudy, W. (1984). The universities of Europe, 1100-1914: a history. Fairleigh Dickinson University Press.

Ruegg, W. (2004). Universities in the Nineteenth and Early Twentieth Centuries (18001945) (Vol.3 of 'A History of the University in Europe'), Cambridge: Cambridge University Press.

Sayer, A. (2010). Method in Social Science: Revised 2nd Edition. London: Routledge.

Schön, D. A. (1983). The reflective practitioner: How professionals think in action (Vol. 5126). Basic books.

Simpson, R. (1983). How the PhD Came to Britain. A Century of Struggle for Postgraduate Education. SRHE Monograph 54. Society for Research into Higher Education, University of Surrey, Guildford, Surrey.

Southern, R. (1970). Western Society and Church in the Middle Ages, London: Penguin. Strauss, J. (2008). 'Is there a Global Warming of Patents?' Journal of World Intellectual Property, DOI: 10.1111/j.1747-1796.2008.00334.

Weber, M. (1905). The Protestant Ethic and the Spirit of Capitalism.

Waquet, F. (2001). Latin: or, the empire of a sign, London: Verso. 


\section{Bibliographical notes}

Tom Bourner is Emeritus Professor of Personal and Professional Development at the University of Brighton. Until his retirement he headed up research in the Business School and before that he led the Management Development Research Unit. Tom's interest in graduate employment goes back over 30 years and his first published work in this field was at the time of the graduate unemployment crisis in the early 1980s. Together with Asher Rospigliosi and Sue Greener, he developed 'new vocationalism', a radically different approach to graduate employability.

Pericles 'asher' Rospigliosi is principal lecturer in e-business, digital marketing and management information systems. He has researched and taught at Brighton Business School since 2001 and has developed successful modules in e-commerce, mobile innovations, big data and digital marketing. Asher has research interests in the history, role and nature of higher education, graduate employability and how graduates might best be served by university as well as e-commerce, digital marketing, big data and digital entrepreneurs. With Tom Bourner and Sue Greener he has researched 'new vocationalism', an approach to graduate employability which emphasises the demonstration of a capacity and disposition to learn within employment.

Dr Linda Heath has worked within the field of Education for more than 35 years. Her background is in the field of Education with Psychology and she has wide experience of all ages at all stages of the educational process. For the past 25 years she has worked as a Senior Lecturer at the University of Brighton both in the School of Education and Brighton Business School. Linda has particular interest in issues relating to learning in Higher Education and has undertaken several pieces of research with her two colleagues on the tripartite mission of the university from the earliest universities to the modern day. 